\title{
Characterization of Temperature Response of Asymmetric Tapered-Plastic Optical Fiber- Mach Zehnder Interferometer
}

\author{
Ian Yulianti 1,a,*, Ngurah Made Darma Putra ${ }^{1, \mathrm{~b}}$, Fianti ${ }^{1, \mathrm{c}}$, Abu Sahmah Mohd Supa'at ${ }^{2, \mathrm{~d}}$, \\ Helvi Rumiana ${ }^{1, \mathrm{e}}$, Siti Maimanah ${ }^{1, \mathrm{f}}$, and Kukuh Eka Kurniansyah ${ }^{1, \mathrm{~g}}$ \\ ${ }^{1}$ Physics Department, Faculty of Mathematics and Natural Sciences, Universitas Negeri Semarang \\ Gd. D7 1t.2, Sekaran, Gunungpati, Semarang 50229, Indonesia \\ ${ }^{2}$ School of Electrical Engineering, Faculty of Engineering, Universiti Teknologi Malaysia \\ Skudai, Johor Bahru, Malaysia \\ e-mail: a ianyulianti@mail.unnes.ac.id, ${ }^{b}$ ngurahmade_dp@mail.unnes.ac.id, ${ }^{c}$ fianti@mail.unnes.ac.id, \\ dabus@fke.utm.my, ${ }^{\mathrm{e}}$ helvirumiana28@gmail.com, ${ }^{\mathrm{f}}$ maimanah.mae@gmail.com, \\ and ${ }^{\mathrm{g}}$ officialkukuh24@gmail.com \\ *Corresponding author
}

\begin{abstract}
Temperature measurement is important in various applications; therefore, various temperature sensors have been developed. Due to its advantages, many optical fiber-based temperature sensors have been proposed. The wavelength modulation-based optical sensor is interesting due to high accuracy. However, the complex fabrication process and high cost limit the advantages of the sensors. Therefore, we proposed a simple and low-cost Mach Zehnder interferometer (MZI) sensor using step-index plastic optical fiber (SI-POF). Performance characterization of the sensor to temperature variation is presented. The sensor consists of two tapers at several distances, forming an interferometer. The first taper was designed to be steep to allow excitation of cladding modes, while the second taper was gradual to suppress power loss. Characterizations were done in terms of sensitivity, hysteresis, and repeatability by analyzing the output spectrums recorded by the spectrometer at various environment temperatures, $35^{\circ} \mathrm{C}$ to $85^{\circ} \mathrm{C}$, with an increment of $10^{\circ} \mathrm{C}$. The results showed that the sensor has a sensitivity of $0.0431 \mathrm{~nm} /{ }^{\circ} \mathrm{C}$ and a correlation coefficient of 0.9965 . Hysteresis of $6.9 \times 10^{-3}$ was observed. In terms of repeatability, the sensor shows a maximum deviation, $\pm 3^{\circ} \mathrm{C}$, which was mainly resulted from the fluctuation of the oven temperature. Despite its high deviation, the sensor has advantages of simple fabrication, low cost, robust, and low power loss, which make it a good candidate for temperature sensors.
\end{abstract}

Keywords: Mach-Zehnder interferometer; SI-POF; Temperature measurement

\section{Karakterisasi Respon Suhu Fiber Optik Plastik Taper Asimetri berbasis Mach-Zehnder Interferometer}

\begin{abstract}
Abstrak
Pengukuran suhu merupakan hal yang penting dalam berbagai aplikasi, oleh karena itu berbagai sensor suhu telah dikembangkan. Sensor suhu berbasis serat optik telah banyak dikembangkan karena sensor berbasis serat optik memiliki banyak keunggulan. Di antara jenis sensor optik yang ada, sensor optik
\end{abstract}


Jurnal Penelitian Fisika dan Aplikasinya (JPFA), 2020; 10(1): 34-43

berbasis modulasi panjang gelombang menarik karena memiliki akurasi yang tinggi. Namun, sensor jenis ini memiliki kelemahan berupa proses fabrikasi yang kompleks dan biaya tinggi. Oleh karena itu, dalam penelitian ini digunakan sensor Mach Zehnder interferometer (MZI) yang sederhana dan murah menggunakan step index plastic optical fiber (SI-POF). Sensor terdiri dari dua bagian lancip (taper) yang terpisah dan membentuk interferometer. Taper pertama dibuat agak curam untuk memungkinkan terjadinya eksitasi pada mode cladding, sedangkan kemiringan taper kedua dibuat lebih landai untuk menekan kehilangan daya. Karakterisasi dilakukan untuk memperoleh sensitivitas, histeresis, dan pengulangan dengan menganalisis spektrum keluaran yang direkam oleh spektrometer pada berbagai suhu lingkungan yaitu $35^{\circ} \mathrm{C}$ hingga $85^{\circ} \mathrm{C}$ dengan kenaikan $10^{\circ} \mathrm{C}$. Hasil penelitian menunjukkan bahwa sensor memiliki sensitivitas $0,0431 \mathrm{~nm} /{ }^{\circ} \mathrm{C}$ dengan koefisien korelasi 0,9965 dan histeresis sebesar $6,9 \times 10^{-3}$. Dalam hal pengulangan, sensor menunjukkan deviasi maksimum $\pm 3^{\circ} \mathrm{C}$ yang dihasilkan dari fluktuasi suhu oven. Meskipun memiliki deviasi tinggi, sensor ini memiliki kelebihan yaitu proses fabrikasi sederhana, biaya rendah, kuat, dan rugi daya yang rendah menjadikannya sebagai kandidat yang baik untuk sensor suhu.

Kata Kunci: Mach-Zehnder interferometer; SI-POF; pengukuran suhu.

PACS: 42.81.-I; 07.07.Df; 42.81.Pa.

(C) 2020 Jurnal Penelitian Fisika dan Aplikasinya (JPFA). This work is licensed under CC BY-NC 4.0

Article History: Received: January 16, 2020

Accepted: June 29, 2020
Approved with minor revision: May 23, 2020

Published: June 30, 2020

How to cite: Yulianti I, et al. Characterization of Temperature Response of Asymmetric Tapered-Plastic Optical Fiber-Mach Zehnder Interferometer. Jurnal Penelitian Fisika dan Aplikasinya (JPFA). 2020; 10(1): 34-6. DOI: https://doi.org/10.26740/jpfa.v10n1.p34-43.

\section{INTRODUCTION}

The importance of temperature measurement in various applications such as environmental monitoring, chemical industry, and the automotive industry has triggered the development of temperature sensors with various technology. As optical fiber sensor technology evolves, research on the optical sensor for temperature measurement has also been reported numerously. Optical fiber based-temperature sensor is impressive due to its advantages such as free from electromagnetic interference, suitable for the hazardous environment, and can be arranged in a multiplexed array.

Various configurations and techniques have been used to develop optical fiber temperature sensor, such as metal-coated fiber Bragg grating (FBG) [1]; multimode interference (MMI) using no core fiber Ian Yulianti, et al
(NCF) [2]; the interferometric sensor comprises suspended-core fiber (SCF) spliced with two single-mode fibers (SMFs); [3] and liquid-filled photonic crystal fiber (PCF) [4]. All the previous-mentioned sensors principle are based on wavelength modulation technique. The wavelength-based modulation technique is interesting since the measurement is not affected by power loss due to bending, fiber connection, and light source fluctuation. However, the complicated fabrication process and high cost of PCF limit the advantages of the sensor.

Other wavelength based sensor is the Mach Zehnder interferometer (MZI) based optical sensor. MZI based sensors provide advantages such as high sensitivity, applicable for remote sensing, and does not require other optical devices such as coupler 
or splitter [5]. MZI configuration has been demonstrated to measure physical and chemical parameters such as humidity [6,7], torsion [8], ammonia [8], refractive index $[9,10]$, and strain [11].

For temperature measurement, the MZI sensor has been realized by using various techniques such as SMF spliced with NCF and waist enlarged taper [5] and microstructured optical fiber (MOF) between two SMFs [12]. The sensors provide high sensitivity, which is in the order of $10^{-1} \mathrm{~nm} /{ }^{\circ} \mathrm{C}$. MZI using PCF for temperature measurement was reported, which has a sensitivity of $30.98 \mathrm{pm} /{ }^{\circ} \mathrm{C}$ at a wavelength range of $30^{\circ} \mathrm{C}$ to $80^{\circ} \mathrm{C}$ [13]. The MZI consist of PCF spliced between two spherical SMF. Gong et al. [14] proposed MZI coated with polydimethylsiloxane (PDMS). The MZI structure was realized by forming mismatch three SMF segments through the core-offset fusion splicing method. The PDMS coating was fabricated by using a mold. The sensor showed a sensitivity of $0.101 \mathrm{~nm} /{ }^{\circ} \mathrm{C}$. To improve the sensitivity, Tong et al. [15] proposed the same MZI structure proposed by Gong et al. [14] and cascaded it with FBG. The sensitivity was $10.389 \mathrm{~nm} /{ }^{\circ} \mathrm{C}$ for a temperature range of $10^{\circ} \mathrm{C}$ to $59.4^{\circ} \mathrm{C}$.

Although the devices, as mentioned earlier, provide high sensitivity, the sensor's structure is fragile due to the nature of silica fiber, which limits their lifetime and durability. Another disadvantage of the previous-mentioned sensors is that the fabrication process was complicated. Therefore, it is essential to design the MZI temperature sensor with high robustness with a simple fabrication technique.
A robust optical sensor can be realized using plastic optical fiber (POF) since it has high mechanical strength [16]. POF has been used for various sensor applications such as liquid level sensor [17], ammonia [18], biosensor [19], nitrite detection [20] and refractive index [21]. POF based MZI (POF-MZI) has been demonstrated for refractive index and strain measurement [22]. The MZI was constructed by using a simple heat-pull technique on graded index-POF (GIPOF). The results showed that the sensor has comparable sensitivity to both refractive index and strain. However, the sensor suffers from high power loss due to inefficient coupling between POF with SMF.

Considering the high thermo-optic coefficient (TOC) and a high coefficient of thermal expansion (CTE) of POF material [5][23], POF MZI can be adopted for temperature measurement. Therefore, in this paper, the characterization of inline MZI on POF for temperature measurement is presented. The study aims to obtain the temperature response of POF MZI, which were sensor sensitivity, repeatability, and hysteresis to temperature change. Knowledge of temperature response of POF MZI is also important in optimizing MZI design for other applications such as refractive index and strain to avoid measurement error due to temperature variation.

Instead of using GI-POF, the proposed sensor used step-index POF (SI-POF) since SI-POF provides a higher dimension (about $1000 \mu \mathrm{m})$. Hence it sturdier than GI-POF. Besides, SI-POF MZI has the advantage of low-cost interrogation systems since it uses low-cost white LED as a light source and VISNIR spectrometer as a detector. It does not require coupling to SMF since the SI-POF can be connected directly to LED and spectrometer using a SMA 905 connector. Therefore, power loss can be reduced. In addition, the proposed MZI has asymmetric 
tapers. The first taper was designed to be steep to allow excitation of cladding modes, while the second taper was gradual to provide adiabatic mode evolution to reduce power loss. From the author's best knowledge, the characterization of SI-POF based MZI for temperature measurement has not been reported.

\section{METHOD}

The research methodology was carried out, including sensor design, fabrication, and sensor characterization at various temperatures. Through the characterization, sensitivity, hysteresis, and sensor repetition are obtained.

\section{Design and Sensor Operation Principle}

MZI was basically designed by splitting input light into two different path lengths by branching the light path. Due to the difference in path lengths, light propagate with different phase. The branches are then re-combined so that interference occurs in the output. Light splitting can also be done by forming a fiber taper [23]. In this work, MZI was developed by using two tapers with different waist diameters (asymmetric taper) separated at several distances, as shown in Figure 1.

Core modes that initially confined in fiber core excite cladding modes due to tapered structure at the first taper.
The excited cladding modes then propagates across the interferometer region, $L$. At the second taper, light travels at the core and cladding are then recombined and interference as output light. The transmission intensity of output light is defined by Jasim et al. [22].

$$
I_{\text {out }}=I_{1}+I_{2}+2 \sqrt{I_{1} I_{2}} \cos \Delta \phi
$$

where $\Delta \phi$ is the phase difference between core modes and cladding modes, which is defined by

$$
\Delta \emptyset=\frac{2 \pi}{\lambda} \int\left(n_{\text {clad }}-n_{\text {core }}\right) d z
$$

$I_{1}$ and $I_{2}$ are the intensity of light propagation at core and cladding, respectively. $\lambda$ is the wavelength of the light propagates along MZI, and $n_{\text {core }}$ and $n_{\text {clad }}$ is the effective refractive index of core modes and cladding modes, respectively. For SI-POF, the refractive index along core and cladding remains constant; thus, equation (2) can be written as

$$
\Delta \phi=(2 \pi / \lambda) \Delta N_{e f f} L
$$

where $\Delta N_{\text {eff }}=n_{\text {clad }}-n_{\text {core }}$ and $L$ is the optical route length of the interferometer. If the phase difference satisfies $\Delta \phi=(2 k+1) \pi$, where $k$ is an integer, maximum transmission intensity occurs. Therefore, peak wavelength $\left(\lambda_{p}\right)$ of transmission spectra occurs at

$$
\lambda_{p}=2 \Delta N_{e f f} L /(2 k+1)
$$

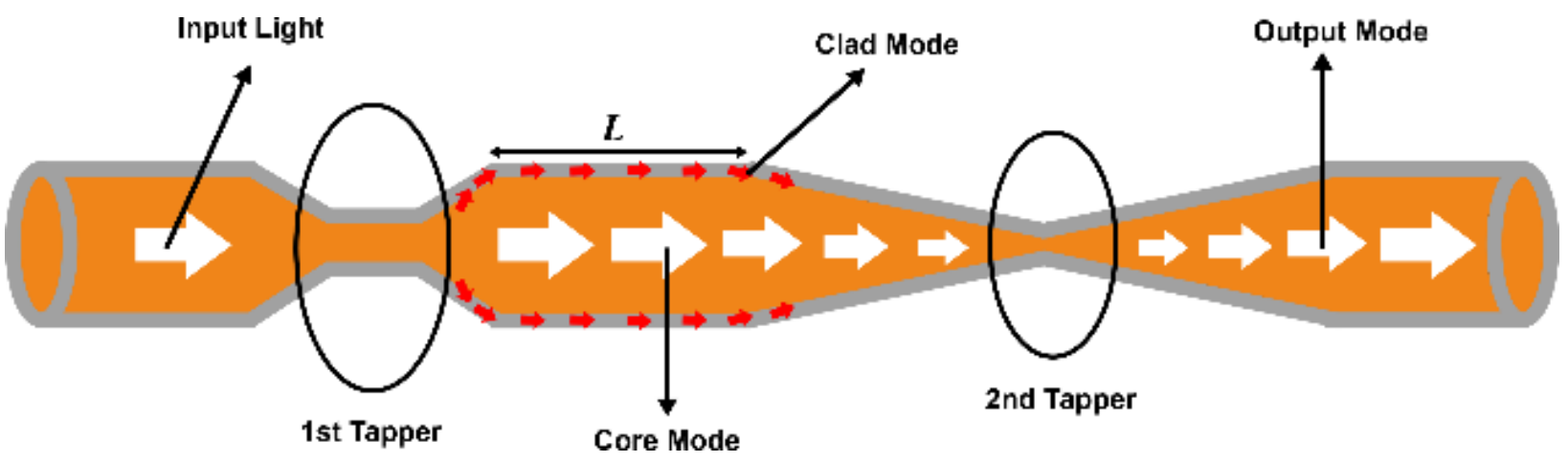

Figure 1. Schematic Diagram of SI-POF MZI 
Due to the thermal properties of POF material, which is Poly(methyl methacrylate) (PMMA), $n_{\text {core }}, n_{\text {clad }}$ and $L$ depend on temperature related by TOC and CTE of the fiber, respectively. For PMMA, the TOC and CTE are $-1.2 \times 10^{-4}$ and $0.68 \times 10^{-4} /{ }^{\circ} \mathrm{C}$, respectively [23]. Thus, any change of temperature of fiber and its surrounding will change the peak wavelength of the MZI transmission spectrums defined by

$$
\frac{d \lambda_{p}}{d T}=\frac{2}{(2 k+1)}\left(\Delta N_{e f f} \frac{d L}{d T}+L \frac{d \Delta N_{e f f}}{d T}\right)
$$

\section{Fabrication and Characterization}

MZI was constructed in SI-POF with a core diameter of $980 \mu \mathrm{m}$ (CC2-1000, Sichuan Huiyuan Plastic Optical Fiber Co., Ltd.). The core material and cladding material are PMMA and fluorinated polymer with a refractive index of 1.49 and 1.41 , respectively. Tapers were formed by heating the POF using solder at a temperature of $80^{\circ} \mathrm{C}$ at two different points and then full it [22]. Before heating, the polyethylene jacket with a diameter of $2.2 \mathrm{~mm}$ was removed at where the tapers to be located using a fiber stripper and cleaned using alcohol. The POF tips were polished using a fiber polishing kit to obtain smooth fiber tips, and then SMA 905 connector (Industrial Fiber Optics, Inc) was coupled to one of the tips. While heated, the output spectrums were observed by connecting the tip with SMA 905 connector to the VIS-NIR spectrometer (USB4000, Ocean Optics), and the other tip was connected to white LED. To measure the waist diameters and to observe the tapers shapes, the tapers were viewed using a CCD-optical microscope.

Sensor characteristics to temperature change i.e., sensitivity, hysteresis, and repeatability, were obtained by performing sensor characterization. The sensor was placed in our modified temperature controlled-oven, while the tips connected to the spectrometer and LED, as shown in Figure
2. The oven temperature was increased from $35^{\circ} \mathrm{C}$ to $85^{\circ} \mathrm{C}$ with an increment of $10^{\circ} \mathrm{C}$ and was kept at each value for 1 minute before being further increased. The spectrum was recorded every 1 second. The sensor was then taken out from the oven and let it in room temperature before conducting characterization for decreased temperature. The cycle was repeated for three times measurement.

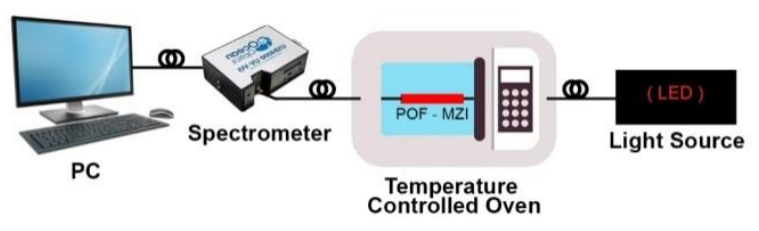

Figure 2. Characterization Set Up of the SI-POF MZI

\section{RESULTS AND DISCUSSION}

Figure 3 shows a side view of the first taper and the second taper of the fabricated MZI taken by an optical microscope. The waist diameters obtained were $872 \mu \mathrm{m}$ and $678 \mu \mathrm{m}$ for the first taper and second taper, respectively, while the interferometer region was $20 \mathrm{~mm}$.

The normalized transmission spectrum of the sensor at room temperature is shown in Figure 4. As can be seen from the figure, three main peaks occurred over the spectral range of 450-650 $\mathrm{nm}$. It also can be observed that the sensor provides low loss over the spectral range with a maximum loss of $<-7.5 \mathrm{~dB}$ at a wavelength of $450 \mathrm{~nm}$. As expected, the power loss is much lower than that of GI-POF [22]. Compared to SMF-based MZI sensors such as [14] and [15], the loss is up to $80 \%$. The primary power loss occurred due to the connection between POF and LED since the sensor tip was directly attached to a LED without using a connector. Low power loss is essential, especially in multiplexed optical sensors, to improve the signal to noise ratio (SNR). 


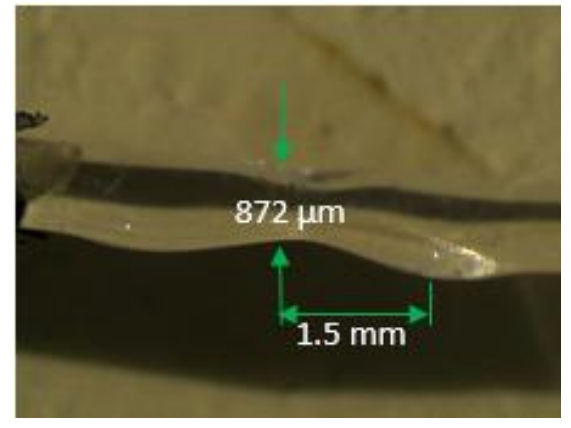

(a)

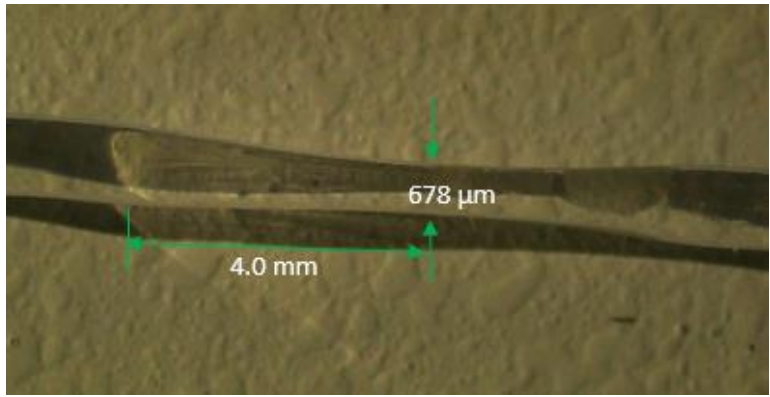

(b)

Figure 3. Optical Microscope Image of the First Taper (a) and Second Taper of the Fabricated POF-MZI

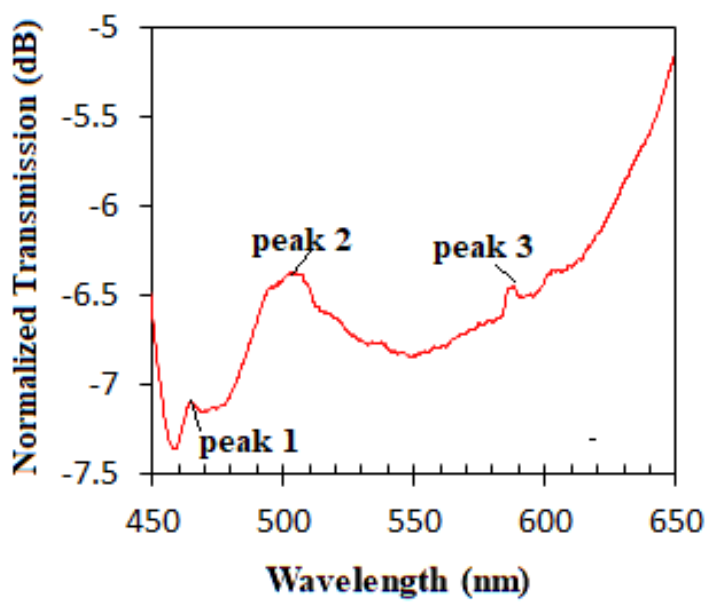

Figure 4. Transmission spectrums at room temperature of the fabricated POF-MZI

As the sensor was subjected to temperature change, the locations of the peaks were red-shifted. The results agree with other MZI-based temperature sensors [14,15,24]. Peak analysis showed that peak 3 provides the highest sensitivity and lowest data hysteresis. The sensor spectrum at various temperature values at a wavelength ranging from $570 \mathrm{~nm}$ to $610 \mathrm{~nm}$, in which peak 3 is located, is shown in Figure 5. The red-shift occurred since, even though the refractive index of both core and cladding were decreased due to the negative TOC, the first term of Equation (5) is higher than the second term, which results in positive wavelength change.

It also can be observed from Figure 5 that power loss is decreased as temperature increased, which is the effect of the decrease of POF Young's modulus, which leads to a reduction of stress on fiber and further results in the reduction of power loss [16]. The decrease of power loss also due to the negative TOC of the POF. Since the absolute TOC of the core is smaller than that of cladding, it increases the numerical aperture [25][26][27].

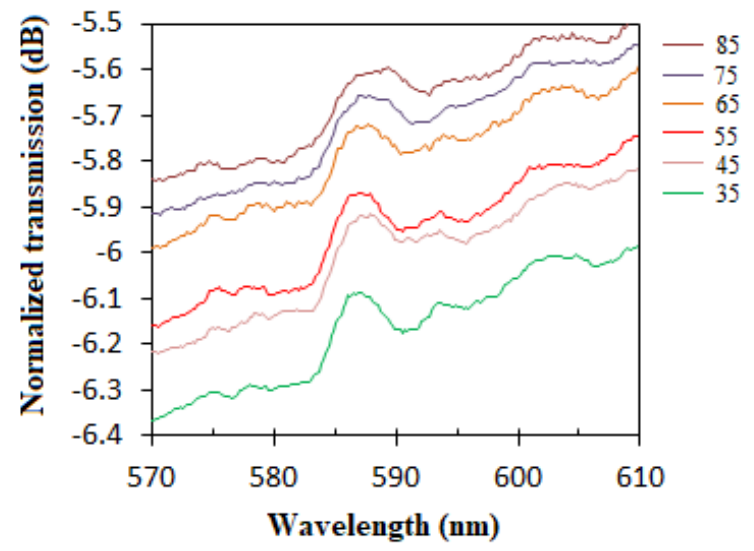

Figure 5. Transmission spectrums of POF-MZI at various temperature values

The peak wavelengths corresponding to each temperature value, obtained from three cycles of measurement, were averaged and then plotted against temperature to obtain the sensor's calibration curve. The averaged wavelength of peak 3 as a function of temperature is shown in Figure 6. It is shown that the sensor provides a sensitivity of 0.0431 $\mathrm{nm} /{ }^{\circ} \mathrm{C}$ with a correlation coefficient of 0.9965 . The linear regression equation is defined by

$\lambda(\mathrm{nm})=0.0431 T+585.65$

Compared to SMF based-MZI temperature sensor $[5,12]$, the sensor has one order lower sensitivity. However, compared to other wavelength based-temperature sensors, 
such as a no-core fiber sensor [2], fiber Bragg grating sensor (FBG) [1], the proposed MZI provides higher sensitivity. Sensitivity can be further improved by applying coating material with high CTE and TOC to induce more thermal expansion and thermo-optic effect such as polydimethylsiloxane (PDMS) [28] and Molybdenum disulfide (MoS2) [29].

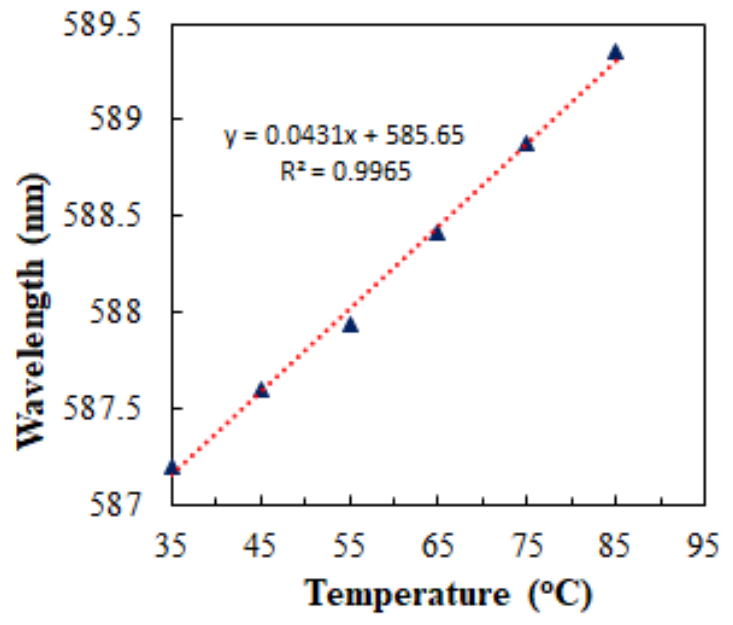

Figure 6. Calibration curve of POF-MZI sensor of peak 3

The wavelength shifts obtained from the increased and decreased temperature of the first cycle are plotted against temperature, as shown in Figure 7. It is clearly seen that the sensor shows hysteresis behaviour as the peak wavelengths did not return to the same values when reversed measurements were conducted. Hysteresis of the sensor was evaluated by calculating the hysteresis value $(\mathrm{H})$ of the first cycle, which is defined by [11]

$$
H=\max (I(i)-D(i)) / I(i)
$$

where $I(i)$ and $D(i)$ is the increased and decreased measurement at temperature $i$, respectively. It was found that the sensor has a hysteresis of $6.9 \times 10^{-3}$. The hysteresis occurred due to the fluctuation of the oven, which was $\pm 2^{\circ} \mathrm{C}$.

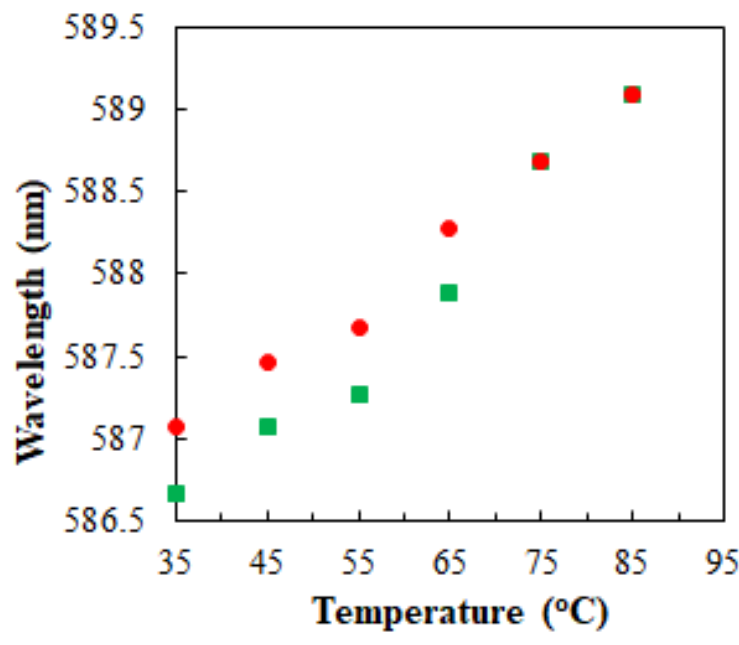

Figure 7. Hysteresis of the fabricated SI-POF MZI

The sensor repeatability was determined by evaluating the maximum difference between different measurements from the average of all measurements when the same experiment process is repeated under the same condition [30]. The peak wavelengths obtained from the measurements were first converted into temperature by using Equation (6). Maximum deviations of each temperature values are plotted against the actual temperatures measured by a thermocouple, as shown in Figure 8. The standard deviation of the graph's data is $1.89^{\circ} \mathrm{C}$; meanwhile, the maximum deviation is $\pm 3^{\circ} \mathrm{C}$. The high deviation is mainly due to the fluctuation of the actual temperature during measurement, which makes the measurement could not be repeated at the same temperature.

By considering the oven's temperature fluctuation and deducing to the maximum deviation, then the sensor repeatability is $\pm 1^{\circ} \mathrm{C}$. The result is comparable with other POF based temperature sensors which the measurement error is $1.48^{\circ} \mathrm{C}$ [16]. The wavelength resolution of the spectrometer, which is $0.1 \mathrm{~nm}$, also limits the peak wavelength determination accuracy. A more stable temperature chamber is required to investigate more accurate sensor repeatability. 
Jurnal Penelitian Fisika dan Aplikasinya (JPFA), 2020; 10(1): 34-43

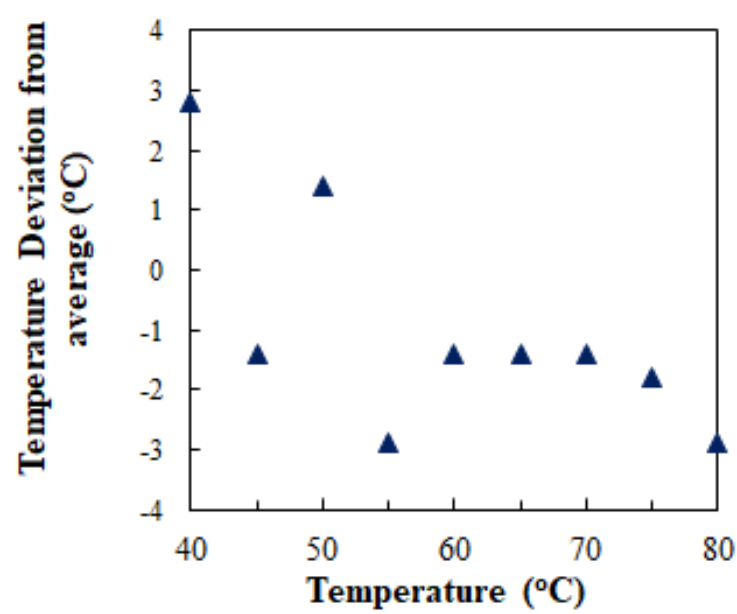

Figure 8. Repeatability of the SI-POF MZI

The obtained results confirm that the MZI structure could be realized by forming two tapers at several distances in SI-POF. It also shows that the interference of light traveled in the cladding and core is affected by the surrounding temperature. Therefore, the structure could potentially be applied for a temperature sensor. On the contrary, if the structure is used for other sensor applications such as refractive index and strain, its temperature dependence will affect the measurement accuracy. Therefore, it quires temperature compensation to reduce the temperature effect.

\section{IV.CONCLUSION}

Based on the results, it can be concluded that the sensor has comparable sensitivity to another wavelength-based sensor with good linearity. However, the sensor has a high deviation. Other sensor advantages are robust, simple fabrication process, low cost, and low power loss. The sensitivity can be further improved by applying coating material with high CTE and TOC. It can also be concluded that temperature variation might contribute to measurement error if the design is used for other refractive index and strain applications. Therefore, the temperature compensation technique should be optimized in designing SI-POF MZI for other applications.

\section{ACKNOWLEDGMENT}

We would like to thank the Ministry of Research, Technology, and Higher Education, Indonesia, for funding the research through Hibah Penelitian Dasar Unggulan Perguruan Tinggi (Higher Education Fundamental Research Grant) with grant no of 042.06.1.401516/2018. Our gratitude also goes to the Physics Department members, Universitas Negeri Semarang, for their helpful discussion throughout the completion of this work.

\section{REFERENCES}

[1] Hsiao TC, Hsieh TS, Chen YC, Huang SC, and Chiang CC. Metal-Coated Fiber Bragg Grating for Dynamic Temperature Sensor. Optik. 2016; 127(22): 10740-10745. DOI: https://doi.org/10.1016/j.ijleo.2016.08.110.

[2] Ma L, Kang Z, Qi Y and Jian S. Fiber-Optic Temperature Sensor Based on a Thinner NoCore Fiber. Optik. 2015; 126(9-10):10441046.DOI:

https://doi.org/10.1016/j.ijleo.2015.02.084.

[3] Villalba A and Martín JC. Interferometric Temperature Sensor Based on a Water-Filled Suspended-Core Fiber. Optical Fiber Technology. 2017; 33: 36-38. DOI: https://doi.org/10.1016/j.yofte.2016.11.006.

[4] Abbasi M, Soroosh M and Namjoo E. Polarization-Insensitive Temperature Sensor Based on Liquid Filled Photonic Crystal Fiber. Optik. 2018; 168: 342-347. DOI: https://doi.org/10.1016/J.IJLEO.2018.04.116.

[5] Hsu JM, et al. Temperature Fiber Sensors Based on Mach-Zehnder Interferometer With Sturdy Structure. IEEE Sensors Journal. 2015; 15(12): 6995-7000. DOI: https://doi.org/10.1109/JSEN.2015.2469670.

[6] Ma Q, Ni K and Huang R. A Carboxy-Methyl Cellulose Coated Humidity Sensor Based on Mach-Zehnder Interferometer with WaistEnlarged Bi-Tapers. Optical Fiber Technology. 2017; 33: 60-63. DOI: https://doi.org/10.1016/j.yofte.2016.11.002. 
Jurnal Penelitian Fisika dan Aplikasinya (JPFA), 2020; 10(1): 34-43

[7] Ni K, Chan CC, Chen L, Dong X, Huang R, and $\mathrm{Ma}$ Q. A Chitosan-Coated Humidity Sensor Based on Mach-Zehnder Interferometer with Waist-Enlarged Fusion Bitapers. Optical Fiber Technology. 2017; 33: 56-59. DOI:

https://doi.org/10.1016/j.yofte.2016.11.005.

[8] Huerta-Mascotte E, Sierra-Hernandez JM, Mata-Chavez RI, Jauregui-Vazquez D, Castillo-Guzman A, Estudillo-Ayala JM, Guzman-Chavez AD, and Rojas-Laguna R. A Core-Offset Mach Zehnder Interferometer Based on a Non-Zero Dispersion-Shifted Fiber and Its Torsion Sensing Application. Sensors. 2016; 16(6). 856. DOI: https://doi.org/10.3390/s16060856.

[9] Wang Q, Kong L, Dang Y, Xia F, Zhang Y, Zhao Y, Hu H, and Li J. High Sensitivity Refractive Index Sensor Based on Splicing Points Tapered SMF - PCF- SMF Structure Mach-Zehnder Mode Interferometer. Sensors and Actuators, B: Chemical. 2016; 225: 213 220. DOI:

https://doi.org/10.1016/j.snb.2015.11.047.

[10] Melo L, Burton G, Kubik P and Wild P. Refractive Index Sensor Based on Inline Mach-Zehnder Interferometer Coated with Hafnium Oxide by Atomic Layer Deposition. Sensors and Actuators, B: Chemical. 2016; 236: 537-545. DOI: https://doi.org/10.1016/j.snb.2016.06.030.

[11] Avila-Garcia MS, Bianchetti M, Corre RL, Guevel A, Mata-Chavez RI, SierraHernandez JM, Jauregui-Vazquez D, ReyesAyona JR, Estudillo-Ayala JM, and RojasLaguna R. High Sensitivity Strain Sensors Based on Single-Mode-Fiber Core-Offset Mach-Zehnder Interferometers. Optics and Lasers in Engineering. 2018; 107: 202-206. DOI:

https://doi.org/10.1016/J.OPTLASENG.201 8.02.008.

[12] Deng M, Liu L, Zhao Y, Yin G, and Zhu T. Highly Sensitive Temperature Sensor Based on an Ultra-Compact Mach-Zehnder
Interferometer with Side-Opened Channels. Optics Letters. 2017; 42(18): 3549-3552. DOI:

https://doi.org/10.1364/OL.42.003549.

[13] Zhao L, Liu B, Wu Y, Mao Y, Sun T, Zhao D, Liu Y, and Liu S. Photonic Crystal All-Fiber Mach-Zehnder Interferometer Sensor Based on Phase Demodulation. Optical Fiber Technology. 2019; 53: 102059. DOI: https://doi.org/10.1016/j.yofte.2019.102059.

[14] Gong J, Shen C, Xiao Y, Liu S, Zhang C, Ding Z, Deng H, Fang J, Lang T, Zhao C, and Chen Y. High Sensitivity Fiber Temperature Sensor Based PDMS Film on Mach-Zehnder Interferometer. Optical Fiber Technology. 2019; 53: 102029. DOI:

https://doi.org/10.1016/j.yofte.2019.102029.

[15] Tong R, Zhao Y, Hu H and Qu J. Large Measurement Range and High Sensitivity Temperature Sensor with FBG Cascaded Mach-Zehnder Interferometer. Optics \& Laser Technology. 2020; 125: 106034. DOI: https://doi.org/10.1016/j.optlastec.2019.1060 $\underline{34}$.

[16] Leal-Junior A, Frizera-Netoc A, Marques C and Pontes MJ. A Polymer Optical Fiber Temperature Sensor Based on Material Features. Sensors. 2018; 18(1): 301. DOI: https://doi.org/10.3390/s18010301.

[17] Jing N, Teng C, Zheng J, Wang G, Chen Y, Wang Z. A Liquid Level Sensor Based on a Race-Track Helical Plastic Optical Fiber. IEEE Photonics Technology Letters. 2017; 29(1): 158-160. DOI: https://doi.org/10.1109/LPT.2016.2630730.

[18] Rithesh Raj D, Prasanth S, Vineeshkumar T $\mathrm{V}$ and Sudarsanakumar C. Ammonia Sensing Properties of Tapered Plastic Optical Fiber Coated with Silver Nanoparticles/PVP/PVA Hybrid. Optics Communications. 2015; 340: 86-92. DOI: https://doi.org/10.1016/j.optcom.2014.11.09 $\underline{2}$. 
Jurnal Penelitian Fisika dan Aplikasinya (JPFA), 2020; 10(1): 34-43

[19] Cennamo N, Varriale A, Pennacchio A, Staiano M, Massarotti D, ZeniL, and D'Auria S. An Innovative Plastic Optical Fiber-Based Biosensor for New Bio/Applications. The Case of Celiac Disease. Sensors and Actuators B: Chemical. 2013; 176: 10081014. DOI:

https://doi.org/10.1016/j.snb.2012.10.055.

[20] Elias SN, Arsad N and Abubakar S. Nitrite Detection Using Plastic Optical Fiber (POF); an Early Stage Investigation towards the Development of Oral Cancer Sensor Using POF. Optik. 2015; 126(21): 2908-2911. DOI: https://doi.org/10.1016/j.ijleo.2015.07.038

[21] Gowri A and Sai VVR. Development of LSPR Based U-Bent Plastic Optical Fiber Sensors. Sensors and Actuators B: Chemical. 2016; 230: 536-543. DOI:

https://doi.org/10.1016/J.SNB.2016.02.074.

[22] Jasim AA, Hayashi N, Harun SW, Ahmad H, Penny R, Mizuno Y, and Nakamura K. Refractive Index and Strain Sensing Using Inline Mach-Zehnder Interferometer Comprising Perfluorinated Graded-Index Plastic Optical Fiber. Sensors and Actuators A: Physical. 2014; 219: 94-99. DOI: https://doi.org/10.1016/j.sna.2014.07.018.

[23] Luo Y, Yan B, Zhang Q, Peng GD, Wen J, Z, and Zhang J. Fabrication of Polymer Optical Fibre (POF) Gratings. Sensors. 2017; 17(3): 511. DOI: https://doi.org/10.3390/s17030511.

[24] Li C, Ning T, Zhang C, Wen X, Li J, and Zhang C. Liquid Level and Temperature Sensor Based on an Asymmetrical Fiber Mach-Zehnder Interferometer Combined with a Fiber Bragg Grating. Optics Communications. 2016; 372: 196-200. DOI: https://doi.org/10.1016/j.optcom.2016.04.02 $\underline{5 .}$
[25] Jing N, Teng C, Zheng J, Wang G, Zhang M, and Wang Z. Optical Fiber Technology Temperature Dependence of Light Power Propagation in Bending Plastic Optical Fiber. Optical Fiber Technology. 2016; 31: 20-22. DOI:

https://doi.org/10.1016/j.yofte.2016.05.006.

[26] Moraleda AT, García CV, Zaballa JZ and Arrue J. A Temperature Sensor Based on a Polymer Optical Fiber Macro-Bend. Sensors. 2013; 13(10): 13076-13089. DOI: https://doi.org/10.3390/s131013076.

[27] Tapetado A, Pinzón PJ, Zubia J and Vázquez C. Polymer Optical Fiber Temperature Sensor With Dual-Wavelength Compensation of Power Fluctuations. Journal of Lightwave Technology. 2015; 33(13): 2716-2723. DOI: https://doi.org/10.1109/JLT.2015.2408368.

[28] Li J, Gai L, Li $\mathrm{H}$ and $\mathrm{Hu} \mathrm{H.} \mathrm{A} \mathrm{High}$ Sensitivity Temperature Sensor Based on Packaged Microfibre Knot Resonator. Sensors and Actuators A: Physical. 2017; 263 : 369-372. DOI:

https://doi.org/10.1016/j.sna.2017.06.031.

[29] Mohanraj J, Velmurugan V, Sathiyan S and Sivabalan S. All Fiber-Optic Ultra-Sensitive Temperature Sensor Using Few-Layer MoS2 Coated D-Shaped Fiber. Optics Communications. 2018; 406: 139-144. DOI: https://doi.org/10.1016/j.optcom.2017.06.01 1.

[30] Wang Z. Intrinsic Fabry-Perot Interferometric Fiber Sensor Based on UltraShort Bragg Gratings for Quasi-Distributed Strain and Temperature Measurements. Dissertation. Virginia: Virginia Polytechnic Institute and State University, 2006. Available from:

https://citeseerx.ist.psu.edu/viewdoc/downlo ad?doi=10.1.1.113.382\&rep=rep1\&type=pdf. 